\title{
Rancang Bangun Smart Lamp Menggunakan Micro Controller Arduino UNO
}

\author{
Roki Hardianto ${ }^{1}$, Chandra Kusuma ${ }^{2}$ \\ ${ }^{1}$ Program Studi Teknik Informatika Fakultas Ilmu Komputer Universitas Lancang Kuning) \\ ${ }^{2}$ Program Studi Sistem Informasi STMIK Dharmapala) \\ (Jl. Yos Sudarso KM. 8 Rumbai, Pekanbaru, Riau, telp. 0811753 2015) \\ e-mail: ${ }^{1}$ roki@ unilak.ac.id, ${ }^{2}$ chandrakusuma2015.ck23@gmail.com
}

\begin{abstract}
Abstrak
Pada jurnal ini kami membuat sebuah system pengendali lampu rumah dengan Mikrokontroler arduino uno R3 menggunakan Android dengan memanfaatkan Fitur speech recognition yang ada pada smartphone android yang dapat dimanfaatkan untuk mengendalikan lampu rumah menggunakan perintah suara., Sehingga untuk menghidupkan atau mematikan lampu rumah tidak lagi dilakukan secara manual, melainkan dengan cara yg lebih mudah yaitu cukup dengan memberikan perintah suara kepada smartphone android yang dihubungkan dengan Arduino melalui Bluetooth. Pengendalian lampu tidak akan bekerja jika smartphone android diluar jarak jangkauan pancaran bluetooth dari bluetooth module karena sambungan bluetooth akan terputus secara otomatis.
\end{abstract}

Kata kunci: arduino, smartlamp, controller, robotika, elektronika.

\begin{abstract}
In this journal we make a home light control system with an Arduino Uno R3 Microcontroller using Android by utilizing the speech recognition feature available on an Android smartphone that can be used to control home lights using voice commands. So that to turn on or turn off the house lights is no longer done manually, but in an easier way, which is enough to give voice commands to an Android smartphone that is connected to Arduino via Bluetooth. Light control will not work if the Android smartphone is outside the Bluetooth emission range from the Bluetooth module because the Bluetooth connection will be disconnected automatically.
\end{abstract}

Keywords: arduino, smartlamp, controller, robotika, elektronika.

\section{Pendahuluan}

Rumah merupakan salah satu kebutuhan pokok manusia yang dijadikan sebagai tempat tinggal dalam jangka waktu tertentu. Fungsi utama rumah digunakan sebagai tempat istirahat setelah lelah beraktivitas dan berkegiatan sehari-hari. Rumah juga berfungsi sebagai tempat beraktivitas antara anggota keluarga atau teman. Agar menjadi hunian yang layak dan nyaman rumah didesain sedemikian rupa sesuai dengan keinginan dan kebutuhan pemiliknya, sehingga penghuni yang berada didalamnya bisa merasa nyaman dan tidak merasa bosan karena memiliki rumah idaman yang sesuai dengan kebutuhan.

(Masykur \& Prasetiyowati, 2016) menyatakan bahwa, "Alat listrik adalah segala peralatan yang pengoperasiannya membutuhkan energi listrik. Pemanfaatan energi listrik saat ini kurang efektif karena banyak peralatan elektronik rumah tangga yang menggunakan energi listrik serta pemakainnya sangat berlebihan. Pemakaian energi listrik yang berlebihan akan menyebabkan kelangkaan listrik. Teknologi saat ini sudah merambah ke dalam kehidupan manusia, seperti adanya pengembangan aplikasi rumah pintar (smart home) yang dapat memberikan kenyamanan, keamanan dan efesien bagi pengguna. Pengendalian jarak jauh 
merupakan pengendalian yang sangat dibutuhkan mengingat efisiensi yang diperoleh dari pengendalian jarak jauh. Pengendalian akan dilakukan secara otomatis sesuai dengan pengendalian yang di lakukan oleh pengguna. Rumah Pintar (Smart Home) merupakan sebuah aplikasi yang dirancang dengan berbantuan komputer yang akan memberikan kenyamanan, keamanan dan penghematan energi yang berlangsung secara otomatis sesuai dengan kendali pengguna dan terprogram melalui komputer pada gedung atau tempat tinggal kita. Teknologi yangdirancangan untuk rumah pintar ini bertujuan untuk memudahkan pemilik rumah dalam memantau kondisi peralatan elektronik yang terhubung dari gadget yang dimiliki."

Seiring dengan perkembangan teknologi, konsep rumah idaman mulai dipadukan dengan teknologi modern guna membantu manusia merasa nyaman dan praktis untuk melaksanakan kegiatan didalamnya. Konsep rumah pintar merupakan hasil teknologi terapan yang menggabungkan antara rekayasa elektronika, informatika dan arsitektur.

(Setiawan, 2015) menyatakan bahwa "mikrokontroler adalah mikroprosesor yang dikhususkan untuk instrumentasi dan kendali. Mikroprosesor merupakan suatu alat elektronika digital yang mempunyai masukan dan keluaran serta kendali dengan program yang bisa ditulis dan dihapus dengan cara khusus. Mikrokontroler merupakan komputer didalam chip yang digunakan untuk mengontrol peralatan elektronik, yang menekankan efesiensi dan efiktifitas biaya. Secara harfiah disebut "pengendali kecil" dimana sebuah sistem elektronik yang sebelumnya banyak memerlukan pendukung seperti IC TTL dan CMOS dapat direduksi/diperkecil dan akhirnya terpusat serta dikendalikan oleh mikrokontroler ini."

Dengan konsep rumah pintar penghuni rumah dapat mengatur semua bagian rumahnya secara otomatis dari ruangan manapun dengan menggunakan sistem yang terintegrasi ke smartphone atau gadget lainnya seperti mematikan televisi, lampu dll. sehingga rumah pintar pun kini menjadi tren dan solusi. Sebagai contoh yaitu para lansia/disabilitas akan kesulitan untuk mematikan lampu pada ruangan yang memiliki jarak cukup jauh, karena harus melakukannya secara manual. Oleh karena itu, apabila seluruh lampu dalam suatu rumah dikendalikan tanpa harus menyalakan saklar secara manual maka peran rumah pintar akan sangat penting untuk memberi kenyamana dan kemudahan bagi penghuninya.

(Giyartono \& Kresnha, 2015) menyatakan bahwa, "Arduino adalah kit elektronik atau papan rangkaian elektronik open source yang di dalamnya terdapat komponen utama yaitu sebuah chip dengan jenis AVR dari perusahaan Atmel. Arduino dikatakan sebagai sebuah platform dari physical computing yang bersifat open source. Pertama-tama perlu dipahami bahwa kata "platform" disini adalah sebuah pilihan kata yang tepat. Arduino tidak hanya sekedar sebuah alat pengembangan, tetapi kombinasi dari hardware, bahasa pemrograman dan Integrated Development Environment (IDE) yang canggih. IDE adalah sebuah software yang sangat berperan untuk menulis program, meng-compile menjadi kode biner dan meng-upload ke dalam memory mikrokontroler."

(Baxter, Hastings, Law, \& Glass, 2008) menyatakan bahwa, "Dalam diskusi sehari-hari dan di forum internet, mikrokontroller sering dikenal dengan sebut $\mu \mathrm{C}$, uC, atau MCU. Terjemahan bebas dari pengertian tersebut, bisa dikatakan bahwa mikrokontroller adalah komputer yang berukuran mikro dalam satu chip IC (integrated circuit) yang terdiri dari processor, memory, dan antarmuka yang bisa diprogram. Jadi disebut komputer mikro karena dalam IC atau chip mikrokontroller terdiri dari CPU, memory, dan I/O yang bisa kita kontrol dengan memprogramnya. I/O juga sering disebut dengan GPIO (General Purpose Input Output Pins) yang berarti : pin yang bisa kita program sebagai input atau output sesuai kebutuhan. Komponen utama didalam papan Arduino adalah sebuah 8 bit dengan merk ATmega yang dibuat oleh Atmel Corporation. Berbagai papan Arduino menggunakan tipe ATmega yang berbeda-beda tergantung dari spesifikasinya., sebagai contoh Arduino Uno menggunakan ATmega328 sedangkan Arduino Mega 2560 yang lebih canggih menggunakan ATmega2560".

(Baxter et al., 2008) menyatakan bahwa, "Untuk memprogram board Arduino, kita butuh aplikasi IDE (Integrated Development Environment) bawaan dari Arduino. Aplikasi ini berguna untuk membuat, membuka, dan mengedit source code Arduino (Sketches, para 
programmer menyebut source code arduino dengan istilah "sketches"). Selanjutnya, jika kita menyebut source code yang ditulis untuk Arduino, kita sebut "sketch" juga ya :). Sketch merupakan source code yang berisi logika dan algoritma yang akan diupload ke dalam IC mikrokontroller (Arduino)."

Berdasarkan latar belakang di atas, maka dalam tugas akhir ini akan dibuat sebuah Sistem pengendali lampu rumah berbasis android menggunakan mikrokontroler arduino yang di harapkan dapat mempermudah dan membantu penghuninya dalam beraktifitas khususnya lansia dan disabilitas (yang masih bisa mengoperasikan smartphone).

(Setiawan, 2015) menyatakan bahwa, "Bluetooth Module HC-06 merupakan module komunikasi nirkabel pada frekuensi $2.4 \mathrm{GHz}$ dengan default koneksi hanya sebagai SLAVE. Sangat mudah digunakan dengan mikrokontroler untuk membuat aplikasi wireless. Interface yang digunakan adalah serial RXD, TXD, VCC dan GND. Built in LED sebagai indikator koneksi bluetooth. Tegangan input antara 3.6- 6V, jangan menghubungkan dengan sumber daya lebih dari 7V. Arus saat unpaired sekitar 30mA, dan saat paired (terhubung) sebesar 10mA. 4 pin interface $3.3 \mathrm{~V}$ dapat langsung dihubungkan ke berbagai macam mikrokontroler (khusus Arduino, 8051, 8535, AVR, PIC, ARM, MSP430, dan lain-lain). Jarak efektif jangkauan sebesar 10 meter, meskipun dapat mencapai lebih dari 10 meter, namun kualitas koneksi makin berkurang".

(Dimas, Sadewo, Widasari, \& Muttaqin, 2017) menyatakan bahwa, "Dibuat pada tahun 1994, teknologi bluetooth dianggap sebagai alternatif nirkabel untuk kabel data dengan bertukar data menggunakan transmisi radio. Nama Bluetooth berasal dari abad kesepuluh Raja Denmark, Harald Blatand atau, dalam bahasa Inggris, Harold Bluetooth. Seperti ceritanya, Raja Blatand membantu menyatukan faksi di bagianapa sekarang Norwegia, Swedia dan Denmark.Demikian pula, teknologi Bluetooth diciptakan sebagai standar terbuka untuk memungkinkan konektivitas dan kolaborasi antara produk yang berbeda dan industri. Efisiensi Bluetooth dengan fungsi energi yang rendah membuatnya sempurna untuk perangkat yang menjalankanuntu kwaktu yang lama pada sumber daya seperti baterai sel koin atau perangkat energy lainya(bluetooth.com.2016). Smartphone merupakan kombinasi fungsi dari perangkat komunikasi dan perangkat penunjang kebutuhan digital lifestyle denganbeberapa fitur multimedia dan organizer".

Adapun tujuan dari penelitian ini yaitu membuat sebuah system pengendali lampu rumah dengan menggunakan smartphone android (menggunakan suara) melalui koneksi bluetooth yang saling terhubung dalam jangkauan koneksi bluetooth.

Sedangkan manfaat penelitian ini diharapkan bisa menciptakan atau mengembangankan sebuah alat yang bisa mengendalikan lampu rumah dengan memanfaatkan smartphone Android.

(Rumimper, 2016) MCB (Miniature Circuit Breaker) adalah komponen dalam instalasi listrik yang mempunyai peran sangat penting. Komponen ini berfungsi sebagai sistem proteksi dalam instalasi listrik bila terjadi beban lebih dan hubung singkat arus listrik (short circuit atau korsleting). Kegagalan fungsi dari $\mathrm{MCB}$ ini berpotensi menimbulkan hal-hal yang tidak diinginkan seperti timbulnya percikan api karena hubung singkat yang akhirnya bisa menimbulkan kebakaran.. Arus nominal yang terdapat pada MCB adalah 1A, 2A, 4A, 6A, 10A, 16A, 20A, 25A, 32A dan lain sebagainya. 


\section{Metode Penelitian}

Pada saat melakukan sebuah penelitian, metodologi penelitian sangat penting sebagai pengumpul data yang akurat. Metode penelitian juga berguna untuk menyusun tahapan-tahapan agar membentuk alur yang sistematis sehingga tujuan atau hasil yang akan dicapai tidak jauh menyimpang dari apa yang ingin dibuat.

\section{Metode Pengumpulan Data}

Untuk memperoleh data tersebut secara lengkap dan akurat dibutuhkan kerjasama dengan pihak-pihak yang terkait, adapun langkah-langkah yang dilakukan untuk pengumpulan data adalah:

\section{a. Observasi}

Pengamatan dan pencatatan yang sistematis terhadap gejala-gejala yang diteliti. Observasi menjadi salah satu teknik pengumpulan data apabila sesuai dengan tujuan penelitian, direncanakan dan dicatat secara sistematis, serta dapat dikontrol keandalan (reliabilitas) dan kesahihannya (validalitas).

b. Dokumentasi

Teknik pengumpulan data dengan dokumentasi ialah pengambilan data yang diperoleh melalui dokumen-dokumen. Keuntungan menggunakan dokumentasi ialah biayanya relatif murah, waktu dan tenaga lebih efisien. Sedangkan kelemahannya ialah data yang diambil dari dokumen cenderung minim, dan kalau ada rata-rata masih jauh dari harapan, maka oleh karena itu peneliti harus pintar-pintar menyaring datanya.

c. Studi Kepustakaan

Pengumpulan data dari buku-buku dan Jurnal yang sesuai dengan tema permasalahan.

d. Metode Analisa

Pada metode ini penulis menganalisa suatu sistem pemantauan melalui Arduino/Raspberry apakah kekurangan dari sistem tersebut. Pada sistem sekarang pengamanan anak masih kurang efektif.

e. Metode Rancangan

Dalam metode perancangan ini kita dapat mengetahui bagaimana sistem itu dirancang dan alat apa saja yang dibutuhkan.

\section{Pengujian}

Pada tahapan ini peneliti akan melakukakan pengujian kepada system yang telah dibangun. Hasil akhirnya adalah baik Mikrokontroler Arduino dalam mengendalikan lampu rumah dengan memanfaatkan smartphone Android.

\section{Hasil dan Pembahasan}

Pada penelitian ini penulis melakukan penelitian tentang bagaimana cara menghidupkan dan mematikan lampu dengan menggunakan Mikrokontroler Arduino, dengan menggunkan perintah suara pada mikrokontroler arduino, sehingga bisa membantu memudahkan penghuni rumah dalam menghidupkan dan ematikan lampu rumah. Dalam penelitian ini menggunakan aplikasi yang telah disediakan gratis di playstore yaitu Borduino.

\subsection{Aplikasi Borduino}

Aplikasi Borduino adalah aplikasi untuk mengendalikan Arduino Ide Melalui Android, pada aplikasi ini terdapat 6 buah fitur, yaitu:

a. Recontooth adalah aplikasi yang ditujukan untuk mengaktifkan 4 buah relay modul.

b. Voicetooth adalah aplikasi untuk mengontrol arduino via voice command (perintah suara), fitur inilah yang di gunakan dalam penelitian yang sedang dilakukan saat ini.

c. textduino adalah aplikasi untuk mengrontrol arduino via tex (tulisan).

d. resertooth adalah aplikasi untuk mengontrol motor servo 180 derajat melalui android.

e. Mobiduino adalah aplikasi untuk mengontrol mobil reemot arduino melalui android

f. keyduitooth adalah aplikasi untuk keypad password bluetooth dengan android 


\subsection{Prinsip Cara kerja}

Arduino digunakan sebagai otak dari system nyala lampu LED otomatis dengan menggunakan perintah suara melalui smartphone android. Pada awalnya Modul bluetooth HC05 harus sudah terkoneksi dengan smartphone android. Kemudian membuka aplikasi Boarduino Voicetooth, lalu memberikan perintah suara ke smartphone. Setelah itu, smartphone menerjemahkan suara yang diterima menjadi tulisan latin sebagai kode. Selanjutnya kode tersebut dikirimkan ke arduino UNO melalui modul bluetooth HC-05. Apabila kode suara yang telah diterjemahkan tadi sesuai dengan kode yang telah diuplod ke arduino UNO, maka arduino akan mengalirkan arus ke LED sehingga LED menyala. Namun apabila kode yang diucapkan tidak sesuai dengan kode pada arduino UNO, maka arduino akan menahan arus dan LED akan mati.

\subsection{Alat Yang Dibutuhkan}
a. 1 buah arduino uno
b. 1 buah bluetooth modul HC-06
c. 4 buah bola lampu
d. 4 buah pitting lampu
e. 1 buah breadboard
f. kabel jumper
g. smartphone android yang terinstal software boarduino

\subsection{Tahapan Pemasangan}

1. Susunlah rangkaian seperti berikut

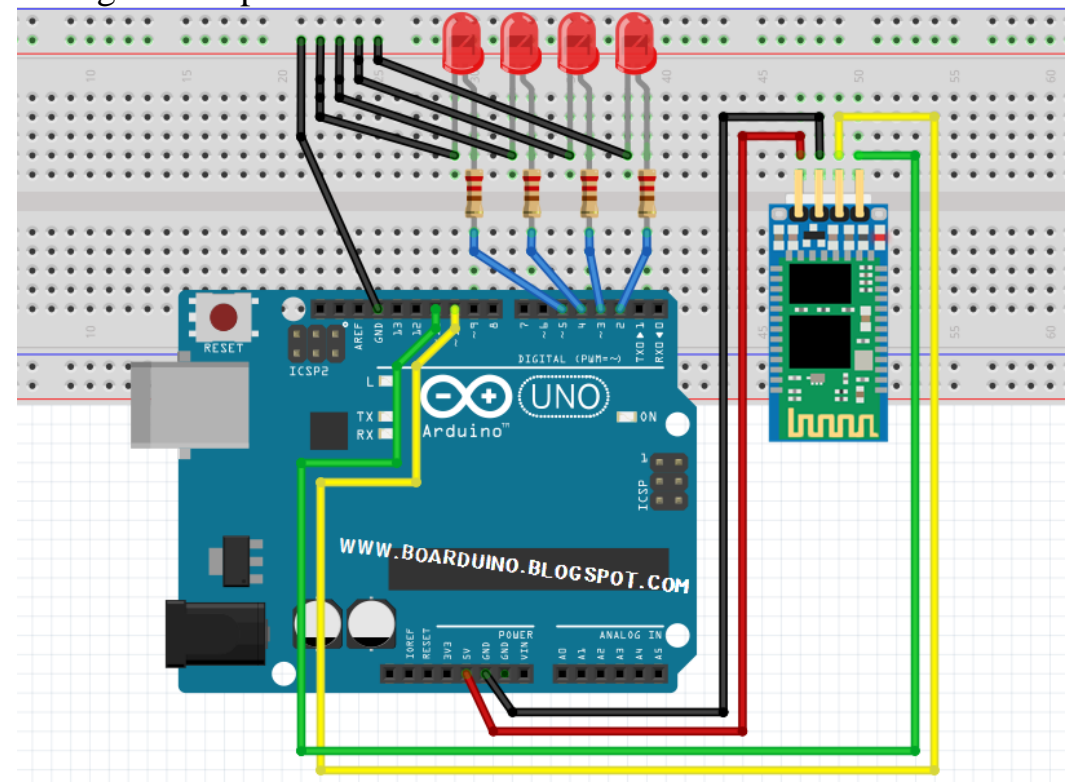

Gambar 1. Rangkaian Arduino

Keterangan Konfigurasi Kabel :

$\checkmark$ Pin VCC pada Arduino dihubungkan ke Pin VCC pada HC-06 / HC-05

$\checkmark$ Pin GND pada Arduino dihubungkan ke Pin GND pada HC-06 / HC-05

$\checkmark$ Pin 10 pada Arduino dihubungkan ke Pin TX pada HC-06 / HC-05

$\checkmark$ Pin 11 pada Arduino dihubungkan ke Pin RX pada HC-06 / HC-05

$\checkmark$ Pin 2 pada Arduino dihubungkan ke Anoda LED 1

$\checkmark \quad$ Pin 3 pada Arduino dihubungkan ke Anoda LED 2

$\checkmark$ Pin 4 pada Arduino dihubungkan ke Anoda LED 3

$\checkmark \quad$ Pin 5 pada Arduino dihubungkan ke Anoda LED 4

$\checkmark$ Hubungkan semua katoda LED1 sampai LED4, lalu di jumper ke GND 


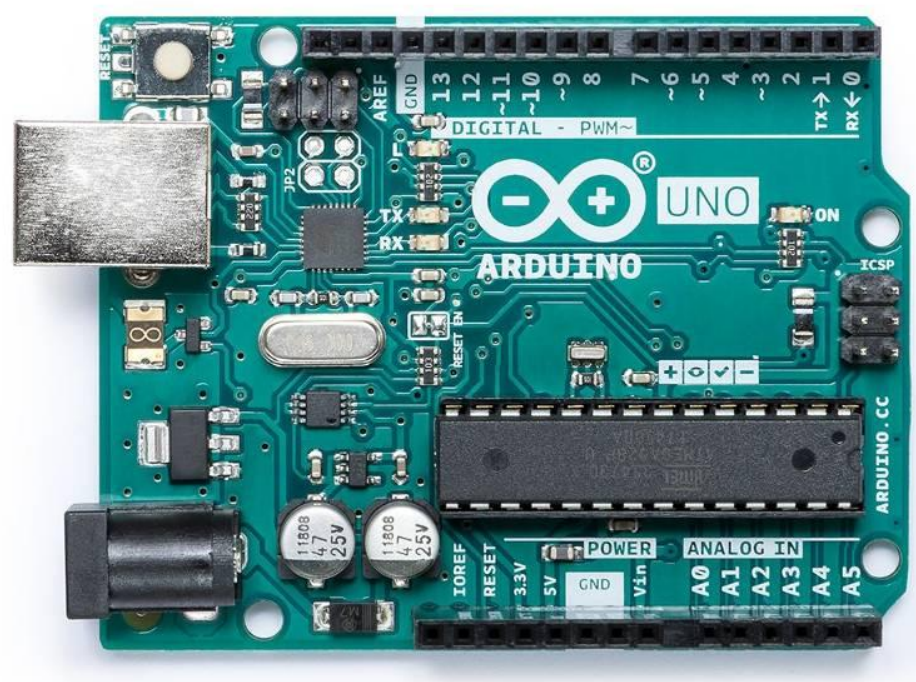

Gambar.2 Arduino Uno

2. Setelah itu sambungkan Arduino pada Laptop/PC dengan menggunakan kabel serial.

3. Download dan Install program Arduino IDE di Arduino.cc ( If Needed )

4. Setelah terinstall, jalankan program Arduino-nya. Klik menu "Tools -> Board -> Arduino Uno".

5. Klik menu "Tools -> Port -> ( Pilih Port arduino yang terdeteksi di komputer anda).

6. Lalu masukan coding dibawah ini, dan terakhir klik upload.

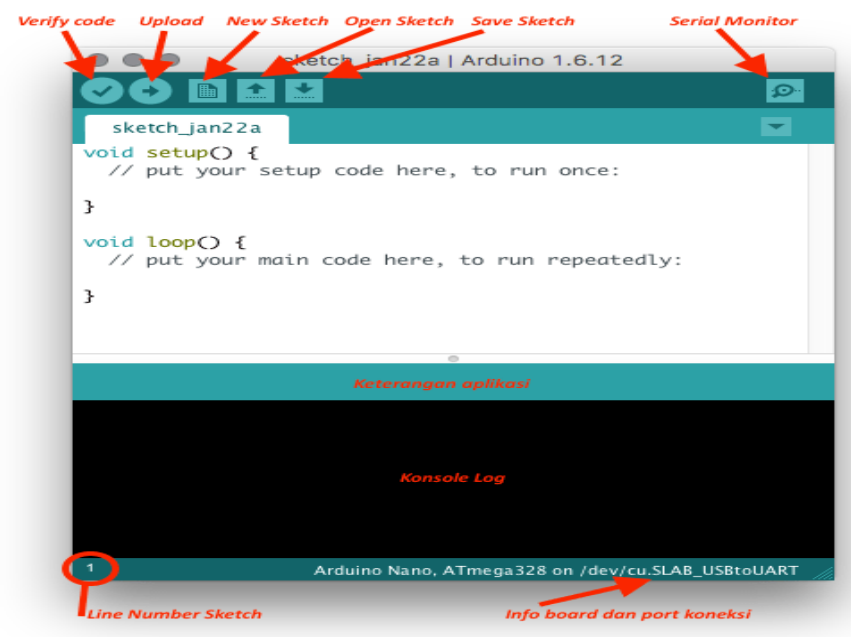

Gambar 3. Teks Editor Arduino 


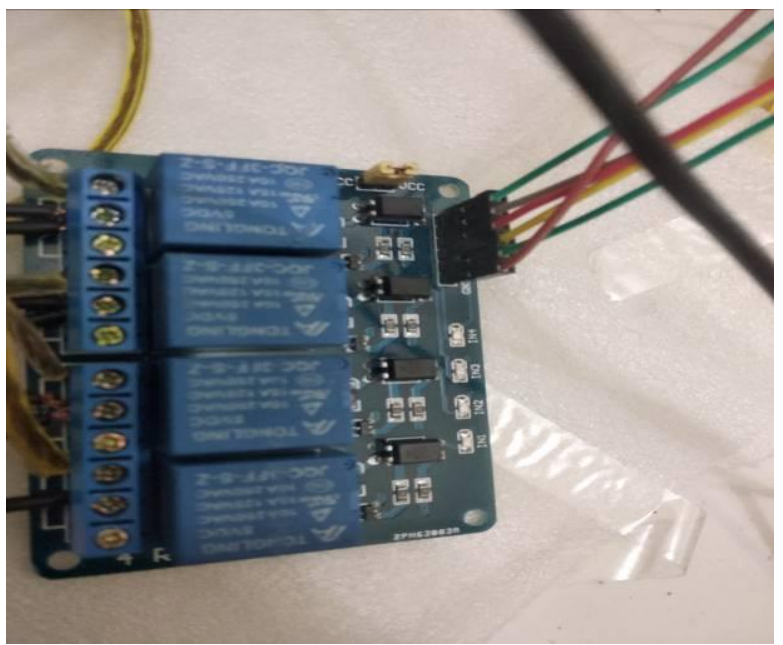

Gambar 4. Relay

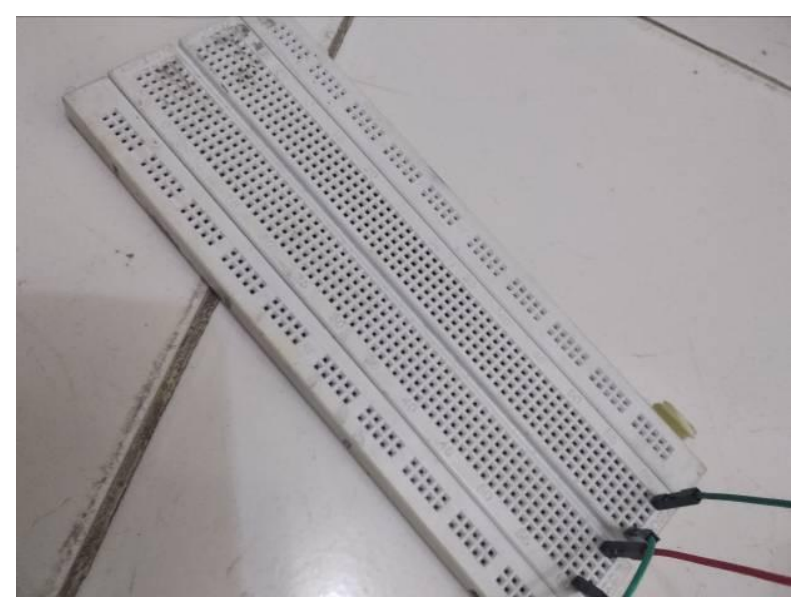

Gambar 5. Projek Board

\#include <SoftwareSerial.h>

SoftwareSerial BT $(10,11)$;

String perintah;

void setup() \{

Serial.begin(9600);

BT.begin(9600);

pinMode(2, OUTPUT);

pinMode(3, OUTPUT);

pinMode(4, OUTPUT);

pinMode(5, OUTPUT);

digitalWrite(2, HIGH);

digitalWrite(3, HIGH);

digitalWrite(4, HIGH);

digitalWrite(5, HIGH);

\}

void loop() \{

while (BT.available())

\{ 


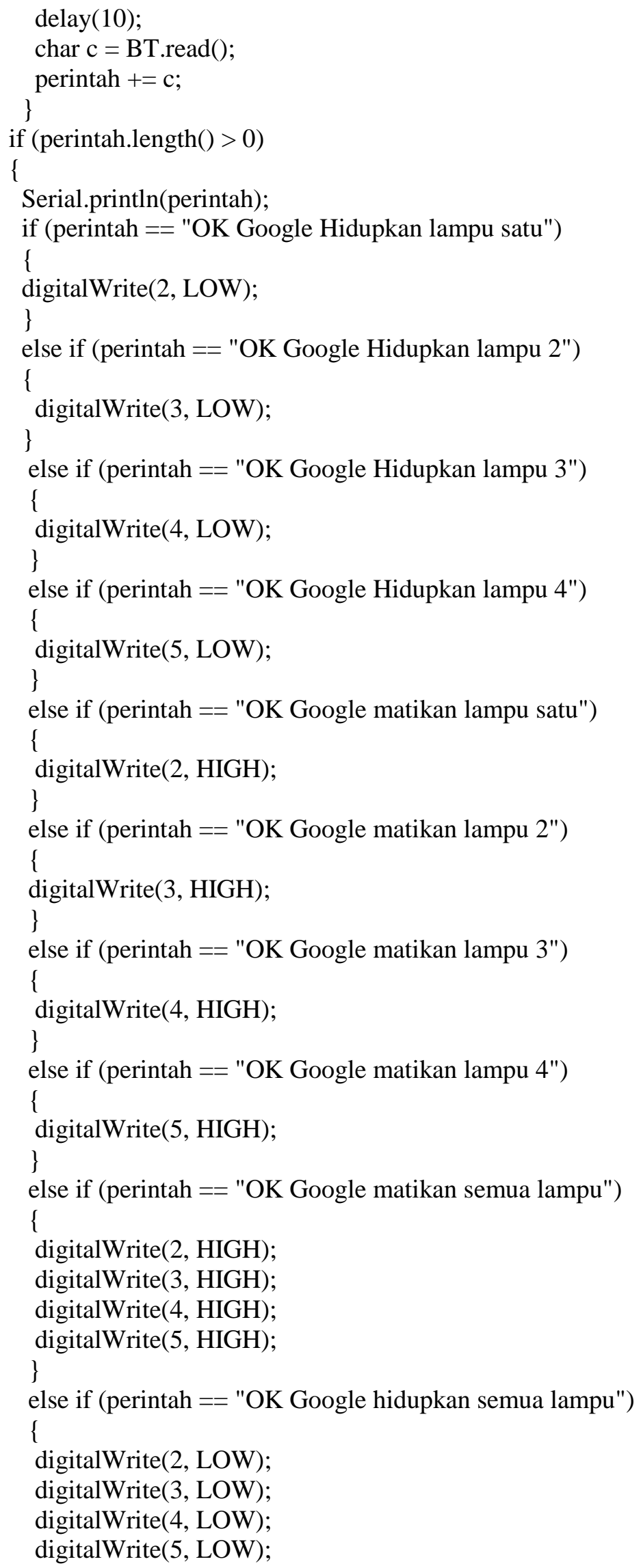




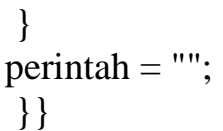

\section{Kesimpulan}

Dari percobaan diatas dapat dilihat bahwa LED akan menyala dan mati ketika diberi perintah suara melalui aplikasi boarduino di Smartphone Android. Perintah yang diucapkan harus sesuai dengan perintah yang ada di script program arduino. Perintah yang diucapkan melalui Smartphone akan diterjemahkan menjadi tulisan yang akan ditampilkan di serial monitor. Saat mengucapkan perintah yang tidak sesuai dengan script di program arduino, maka LED tidak ada akan menyala. Tetapi serial monitor akan tetap menampilkan kalimat yang kita ucapkan. Dan walaupun ucapan kita sesuai dengan perintah tetapi pelafalannya tidak jelas maka aplikasi tidak akan mendeteksi apa yang kita ucapkan. Saat perintah diucapkan dari jarak yang agak jauh (8 meter) masih dapat melakukan perintah untuk menyalakan dan mematikan LED. Karena pada perinsipnya transducer yang kami buat menggunakan Bluetooth Modul HC-06 dimana perintah yang kita ucapkan melalui aplikasi boarduino yang ada di Smartphone akan terhubung ke modul HC-06 melalui bluetooth, sehingga perintah akan tetap bisa dilakukan sejauh jarak jangkauan bluetooth tersebut (10 meter). 


\section{Daftar Pustaka}

[1] Baxter, R., Hastings, N., Law, a., \& Glass, E. J. . (2008). [ No Title ]. Animal Genetics, 39(5), 561-563.

[2] Dimas, A., Sadewo, B., Widasari, E. R., \& Muttaqin, A. (2017). Perancangan Pengendali Rumah menggunakan Smartphone Android dengan Konektivitas Bluetooth. Jurnal Pengembangan Teknologi Informasi Dan Ilmu Komputer, 1(5), 415-425.

[3] Durfee, W. (2011). Arduino Microcontroller Guide. University of Minnesota, 1-27.

[4] Giyartono, A., \& Kresnha, E. (2015). Aplikasi Android Pengendali Lampu Rumah Berbasis Mikrokontroler Atmega328. Seminar Nasional Sains Dan Teknologi, (November), 1-9.

[5] Graham, A., Blentic, A., Duque, S., \& Begbie, J. (2007). Rancang Bangun Aplikasi Android Untuk Kontrol Lampu Gedung Menggunakan Media Bluetooth Berbasis Arduino Uno. Development, 134(23), 4141-4145.

[6] Masykur, F., \& Prasetiyowati, F. (2016). Aplikasi Rumah Pintar (Smart Home) Pengendali Peralatan Elektronik Rumah Tangga Berbasis Web. Teknologi Informasi Dan Ilmu Komputer (JTIIK), 3(1), 51-58.

[7] Nugraha, N., \& Supriyadi, S. (2015). Aplikasi Pengontrolan Lampu Menggunakan Arduino Uno Dengan Algoritma Fuzzy Logic Berbasis Android. Jurnal Teknik Informatika, 1(1), $50-64$.

[8] Rumimper, R. (2016). Rancang Bangun Alat Pengontrol Lampu Dengan Bluetooth Berbasis Android. Teknik Elektro Dan Komputer, 5(3), 24-33.

[9] Setiawan, E. T. (2015). Pengendalian Lampu Rumah Berbasis Mikrokontroller Arduino menggunakan Smartphone Android. Jurnal TI-Atma STMIK Atma LUhur Pangkalpinang, 1-8. https://doi.org/http://dx.doi.org/10.1038/bmt.2015.29

[10] Turesna, G., Zulkarnain, \& Hermawan. (2015). Pengendali Intensitas Lampu Ruangan Berbasis Arduino UNO Menggunakan Metode Fuzzy Logic. J.Oto.Ktrl.Inst (J.Auto.Ctrl.Inst), 7(2), 73-88. 